how significant will the language barrier be for foreign institutions? How difficult will it be for Japanese institutions to offer programs in English or find demand for programs in Japanese overseas? How realistic will it be for Japanese institutions to expect cooperation and assistance from Japanese companies in overseas enterprises? These questions have yet to be answered.

\section{Educating Women Worldwide}

\section{Louise W. Knight}

Louise W. Knight is a historian and former university and women's college administrator who presently teaches at a coeducational university, Northwestern University, in Evanston, Illinois, USA. E-mail: Iwknight@aol.com.

$\mathrm{I}^{\mathrm{n}}$ n every country of the world women lag behind in their development as citizens and leaders. A strong consensus exists among international development organizations, although admittedly not among all national governments, that education is the essential means to correct this imbalance. The question then becomes how best to deliver it. In higher education, as in primary and secondary education, two models are available and both are effective. But while coeducational institutions worldwide have played a crucial role in advancing women, women's colleges and universities have always been and continue to be the beacons, the innovators, and the heart and soul of the international women's education movement. Both their enduring success and a renewed worldwide interest in the single-sex model deserve more attention.

What do women need educationally to fulfill their human potential? In societies that, consciously or unconsciously, treat women as inferior-that is to say, in virtually every society in the world to a varying degree-women need educational affirmation. Access issues aside, they need classrooms where their intellect is respected and their bodies are forgotten, they need a campus life that is not sexually charged, and they need older women as teachers, mentors, and models of what they may become. Coeducational institutions have the potential to provide these things but, to date, these needs are more commonly met at women's colleges and universities. The absence, or minimal presence, of men is part of it, but the institution's priorities are the other, more essential, part.

Women's Separate Higher Education on the Rise

Compared to men's separate higher education, women's separate higher education has a short history. It began in the early 19th century in the United States, and spread to
Europe and Canada, and then was exported around the world by Protestant and Catholic Christian European and American missionaries, many of them graduates of American women's colleges. Later, national governments adopted the model. After a period of relative quiescence in the post-World War II years, the less-than-200-year-old international women's separate higher education movement is vital and spreading. Impressionistic research has revealed that women's colleges and universities have been founded in countries where previously they have been extremely rare-in Africa, much of the Middle East, and China-and their numbers have surged forward in India.

The first woman's university in East Africa, Kiriri Women's University of Science and Technology, was founded just three years ago in Nairobi, Kenya, by a consortium of visionary Kenyan business executives to encourage women to pursue technological education. In the Middle East, the United Arab Emirates has Dubai Women's college, founded in 1989; Saudi Arabia has Effat College, founded in 1999. Both of these are government funded. The state-funded China Woman's College, China's first women's college in the communist era, is less than 10 years old. In India, women's colleges are on the increase. In 1987, there were 780 women's colleges. By 1997, there were 1,195. Finally, a new Asian University for Women, to be based in Bangladesh, is in the planning stage.

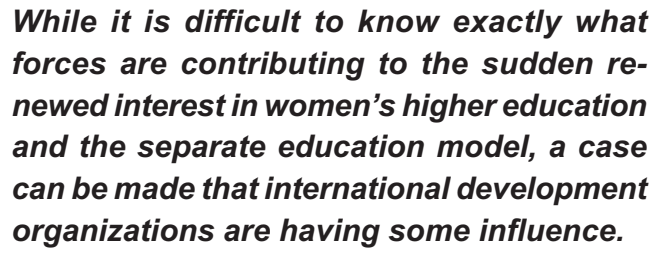

International Interest

While it is difficult to know exactly what forces are contributing to the sudden renewed interest in women's higher education and the separate education model, a case can be made that international development organizations are having some influence. The decision to establish the China Women's College, for example, came in the wake of the 1994 United Nations Fourth World Conference on Women in Beijing. More broadly, under UNESCO's guidance, a strong campaign worldwide to educate all people has been building in recent years, inspired in part by article 26 of the Universal Declaration of Human Rights, adopted by the United Nations in 1948, which reads, "[H]igher education shall be accessible to all on the basis of merit ... Education shall be 
directed to the full development of the human personality." The International Federation of University Women, which promotes women's education worldwide, was founded in the same year. It has consultative status with the United Nations and meets every four years. The international commitment to women's education was affirmed at the 1990 Education for All Conference in Thailand; at the 1998 UNESCO World Conference on Higher Education in Paris; at the 2000 World Education Forum in Dakar, Senegal, which launched the formal Education for All (EFA) Campaign; and at the 2002 United Nations Girls' Education Initiative (UNGEI), in Paris. In response to the EFA campaign, which focuses on primary and secondary education, the World Bank and the International Monetary Fund are both targeting funding toward achieving the goal of gender equity in education worldwide by 2015 . When the campaign turns its attention to higher education, women's colleges and universities, unnoticed in their current discussions, should emerge as of particular interest.

At just the right moment, women's colleges and universities around the world are themselves coming together to promote women's education as an international priority.

Meanwhile, at just the right moment, women's colleges and universities around the world are themselves coming together to promote women's education as an international priority. The leaders of 29 women's colleges and universities from five continents met for the first time this past June, in western Massachusetts, USA, at the invitation of two of the leading American women's colleges, Mt. Holyoke and Smith. The gathering was titled, “Women's Education Worldwide 2004: The Unfinished Agenda." The discussions focused not on the merits of the single-sex method but on their shared commitment to preparing women leaders, both professionally and as agents of social change. The group is just in the early stages of forming-it may soon have a website and a listserv-and it hopes its membership will expand. (Contact: jlytle@mtholyoke.edu) They plan to meet again in two or three years. Indeed, the question of whether coeducational institutions committed to women's education might eventually participate seemed open for further discussion.

Women's education is one of the most powerful tools available for uplifting a nation. It is also a human right that too many women around the world have been denied. Perhaps the 21st century will be the Century for Women's Education Worldwide. It is a revolution longverdue.

\section{The Challenge of Women's Higher Education in Asia}

\section{Patricia B. Licuanan}

Patricia B. Licuanan is president of Miriam College in the Philippines. Address: Miriam College UP, P.O. Box 110, Diliman, Quezon City, Philippines. E-mail: plicuanan@mc.edu.ph.

$\mathrm{T}$ he value of women's education has received global recognition over the past two decades. As early as the 1990 World Conference on Education for All, in Jomtien, Thailand, women's education was cited as a top priority for international development agencies. The "Beijing Platform for Action," the outcome document of the 1995 United Nations Fourth World Conference on Women, in Beijing, focused on 12 critical areas of concern. The education and training of women was one of these critical areas. Governments committed themselves to ensuring equal access to education; eradicating illiteracy among women; improving women's access to vocational training, science, and technology and continuing education; developing nondiscriminatory education and training; allocating sufficient resources for and monitoring the implementation of educational reform; and promoting lifelong training for girls and women.

The "Human Development Report," produced by the United Nations Development Program (UNDP), utilizes the Human Development Index (HDI)) to measure quality of life in a wide range of countries. Through the HDI, specifically through the Gender Differentiated HDI or GDI, which is a measure of gender inequality in the achievement of the basic components of HDI (longevity, knowledge, and income), the importance of gender equality in educational attainment is stressed. In 2000, the United Nations held a Millennium Summit at which world leaders from 189 countries committed themselves to achieve eight Millennium Development Goals (MDGs), with gender equality and women's empowerment as one goal. Goal 3 emphasizes, among other issues, the need to eliminate gender disparity at all levels of education.

\section{A Focus on Higher Education}

While the case for women's education has been eloquently made, there has been considerably more attention to literacy and basic education. The relevance of women's higher education is not revealed in the neglect it has received in most quarters of the international development community for years. The arguments for women's higher education center on human resource development, economic returns, and gender equality and women's empowerment. Women 